\title{
Wide Diversity of Coronaviruses in Frugivorous and Insectivorous Bat Species: A Pilot Study in Guinea, West Africa
}

\author{
Audrey Lacroix ${ }^{1} @$, Nicole Vidal ${ }^{1}$, Alpha K. Keita ${ }^{1,2}$, Guillaume Thaurignac ${ }^{1}$, \\ Amandine Esteban ${ }^{1}$, Hélène De Nys ${ }^{3,4}{ }^{\mathbb{C}}$, Ramadan Diallo ${ }^{5}$, Abdoulaye Toure ${ }^{1,2,6}$, \\ Souana Goumou ${ }^{2}$, Abdoul Karim Soumah ${ }^{2}$, Moriba Povogui ${ }^{2}$, Joel Koivogui ${ }^{2}$, \\ Jean-Louis Monemou ${ }^{2}$, Raisa Raulino ${ }^{1}{ }^{\mathbb{D}}$, Antoine Nkuba ${ }^{1,7}$, Vincent Foulongne ${ }^{8}$,

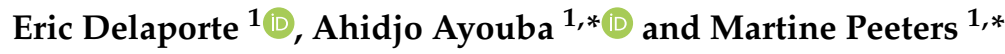 \\ 1 TransVIHMI, Institut de Recherche pour le Développement, University of Montpellier, INSERM, \\ 34394 Montpellier, France; audrey.lacroix@ird.fr (A.L.); nicole.vidal@ird.fr (N.V.); \\ alpha-kabinet.keita@ird.fr (A.K.K.); guillaume.thaurignac@ird.fr (G.T.); amandine.esteban@ird.fr (A.E.); \\ abdoulaye.toure@insp-guinee.org (A.T.); raisa.raulino@ird.fr (R.R.); antoine.nkuba@ird.fr (A.N.); \\ eric.delaporte@ird.fr (E.D.) \\ 2 Centre de Recherche et de Formation en Infectiologie de Guinée (CERFIG), Université Gamal Abder Nasser \\ de Conakry, Conakry BP6629, Guinea; souana.goumou@cerfig.org (S.G.); abdoul.soumah@cerfig.org (A.K.S.); \\ moriba.povogui@cerfig.org (M.P.); joel.koivogui@cerfig.org (J.K.); jean.monemou@cerfig.org (J.-L.M.) \\ ASTRE, CIRAD, INRA, University of Montpellier, 34398 Montpellier, France; helene.de_nys@cirad.fr \\ CIRAD, UMR ASTRE, Harare, Zimbabwe \\ 5 Laboratoire Central de Diagnostic Vétérinaire, Ministère de l'Elevage et des Productions Animales, \\ Conakry BP3982, Guinea; dialloramadan1954@gmail.com \\ 6 Institut National de Sante Publique (INSP), Conakry BP6623, Guinea \\ 7 Institut National de Recherche Biomédicale and Service de Microbiologie, Cliniques Universitaires \\ de Kinshasa, Gombe, Kinshasa P.O. Box 1197, Democratic Republic of the Congo \\ 8 Département de Bacteriologie-Virologie, CHU de Montpellier, 34295 Montpellier, France; \\ v-foulongne@chu-montpellier.fr \\ * Correspondence: ahidjo.ayouba@ird.fr (A.A.); martine.peeters@ird.fr (M.P.)
}

Received: 11 June 2020; Accepted: 3 August 2020; Published: 5 August 2020

\begin{abstract}
Zoonoses can constitute a threat for public health that can have a global importance, as seen with the current COVID-19 pandemic of severe acute respiratory syndrome coronavirus (SARS-CoV2). Bats have been recognized as an important reservoir of zoonotic coronaviruses (CoVs). In West Africa, where there is a high diversity of bat species, little is known on the circulation of CoVs in these hosts, especially at the interface with human populations. In this study, in Guinea, we tested a total of 319 bats belonging to 14 genera and six families of insectivorous and frugivorous bats across the country, for the presence of coronaviruses. We found CoVs in $35(11 \%)$ of the tested bats-in three insectivorous bat species and five fruit bat species that were mostly captured close to human habitat. Positivity rates varied from $5.7 \%$ to $100 \%$, depending on bat species. A wide diversity of alpha and beta coronaviruses was found across the country, including three sequences belonging to SarbeCoVs and MerbeCoVs subgenera known to harbor highly pathogenic human coronaviruses. Our findings suggest that CoVs are widely spread in West Africa and their circulation should be assessed to evaluate the risk of exposure of potential zoonotic CoVs to humans.
\end{abstract}

Keywords: bat; coronavirus; Guinea; virus diversity; Africa 


\section{Introduction}

Emerging infectious diseases (EIDs) represent a significant challenge to global health. The frequency of EID outbreaks has dramatically increased over the last decades. Most EIDs have a zoonotic origin; more than $70 \%$ of them are caused by pathogens originating from wildlife [1]. The continuing encroachment of human populations into areas initially only occupied by wildlife, such as pristine forest - together with environmental and climatic changes-has led to increasing contacts between humans and animals and as a consequence, exposure to the pathogens they harbor [2-4]. The ongoing outbreak with the new severe acute respiratory syndrome coronavirus (SARS-CoV-2), responsible for the COVID-19 pandemic, is a perfect illustration of the potential impact and the global consequences resulting from a single cross-species transmission from an animal virus. The epidemic was first recognized in December 2019 in China and has spread across the entire globe in a few months. By the end of May 2020, more than five million people have been infected; more than 350,000 have died and a lockdown of four billion people across the globe has been enforced to reduce the spread of the virus [5]. It is thus important to be prepared for new EID outbreaks. A major step in understanding the risk for zoonotic infections, is to characterize the diversity of pathogens at the interface between humans and animals. Knowing the animal sources, prevalence, geographic distribution and the genetic diversity or evolutionary history of pathogens in wildlife is critical to evaluate the risk for potential emergence or reemergence of disease.

The current COVID-19 outbreak with the SARS-CoV-2 virus, is the seventh coronavirus (CoV) identified in humans since the 1960s [6,7]. Whereas the initial known human CoVs (HCoV-229E, HCoV-OC43, HCoV-HKU1 and HCoV-NL63) usually cause mild symptoms, the more recent HCoVs have higher pathogenicity and impact. SARS-CoV-1 emerged in 2003, infecting 8000 people in more than 30 countries in a few months, with a lethality of 10\% [8,9]. MERS-CoV emerged in 2012, causing more than 2500 cases in 27 countries to date, with a lethality of 35\% [10-12]. The recent SARS-CoV-2 outbreak has an estimated lethality that is lower than SARS-CoV-1, but the virus was able to spread extremely fast worldwide [13]. All seven HCoVs have a zoonotic origin and evolutionary origin from bats [14-17]. Some have been directly transmitted from bats to humans, but for others an intermediate host was required, like camels for MERS-CoV or civets for SARS-CoV-1 [18-23]. For SARS-CoV-2, the closest relative is identified in a bat from China and the role of an intermediate species, i.e., pangolins, is not clarified yet [24,25].

It is now well established that CoVs are widespread in bats with relative high prevalence and important genetic diversity providing thus multiple opportunities for the potential emergence of novel $\mathrm{HCoVs}$ in areas where contact between humans and bats are frequent [26]. Nevertheless, despite recent efforts, our knowledge on CoVs in bats is far from complete, because most studies are conducted on a limited number of species and in restricted geographic or ecological environments. Bats represent $20 \%$ of all mammals with more than 1400 different species [27]. More studies are thus still needed, especially in areas where the risk for spillover to animals or humans is high, like southeast Asia or West and Central Africa, where numerous bat species are hunted for food or medicine [28-30]. Moreover, bushmeat hunting is recognized as a major threat for conservation of bats in these areas [31,32]. In addition, humans can also be indirectly exposed to bat viruses through contacts with bat guano or fruit contaminated by their saliva, urine or feces [32,33].

Several studies have shown a large diversity of CoVs in bats across Africa, but limited data are currently available on bat CoVs in Sub-Saharan Africa and especially from West Africa, where we have currently only information on bats from Ghana and Nigeria [15,34-42]. Nevertheless, new alpha $(\alpha-\mathrm{CoVs})$ and betacoronaviruses ( $\beta-\mathrm{CoVs})$ have been described in Africa, including some closely related to human CoVs such as HCoV-229E, or SARS-CoVs [15,34,35]. Recently, the closest relatives in bats to the highly pathogenic MERS-CoV were documented in Neoremicia and Pipistrellus bats from South-Africa and Uganda, respectively, illustrating that African bats could also play a role in outbreaks of CoVs in humans [23,43]. Here we conducted a pilot study on the presence of CoVs in bats in Guinea, 
West Africa, a country with a high likelihood for EID outbreaks and where humans are frequently directly or indirectly exposed to bats (A.K. Keita, personal observation).

\section{Materials and Methods}

\subsection{Study Sites, Sample Collection and Ethical Permits}

Samples were collected from free-ranging frugivorous and insectivorous bats in Guinea between February 2016 and January 2017 as previously described [44]. We obtained permission to conduct research and to collect samples from the National Ethics Committee for Health Research (CNERS) from Guinea (approval reference 074/CNERS/15, 26 November 2015). Briefly, bats were captured using mist nets or harp traps in roosting and foraging sites. Bats were then kept in cotton bags and released immediately after sampling. Whole blood was taken by venipuncture of the propatagial or brachial vein and blood drops were directly transferred onto Whatman 903 filter paper (GE-Healthcare, Feasterville-Trevose, PA, USA). Samples were air-dried and preserved individually in plastic bags containing silica desiccant and stored in a hermetic box as dried blood spots (DBS). DBS were stored at $-40{ }^{\circ} \mathrm{C}$ in the laboratory ( 2 to 3 weeks after collection) and kept frozen until analysis. Rectal and oral swabs were also collected in $500 \mu \mathrm{L}$ RNA-later to preserve RNA from degradation and stored in the field at ambient temperature for maximum two weeks and subsequently at $-40{ }^{\circ} \mathrm{C}$ in the laboratory. For a subset of animals, fresh fecal samples were also collected and stored in RNA-later, i.e., feces dropped when bats were in cotton bags. For each sampled bat, information on capture sites (GPS coordinates, ecological environment), capture method, morphology (body measurements, weight, color), sex, age class (adult, juvenile) and visual species identification were recorded.

\subsection{Nucleic Acid Extraction}

Total DNA and RNA were extracted from swabs and feces using the NucliSENS EasyMAG platform (BioMérieux, Marcy-l'Etoile, France). Briefly, $250 \mu \mathrm{L}$ of sample was incubated with $2 \mathrm{~mL}$ of lysis buffer for $15 \mathrm{~min}$ and extraction was performed using manufacturer's instructions. Total nucleic acids were resuspended in $60 \mu \mathrm{L}$ elution buffer.

\subsection{Molecular Confirmation of Bat Species}

Species identification recorded in the field was molecularly confirmed on a subset of bats using DBS as in our previous study on Ebolaviruses in bats [44]. In addition, the species was also molecularly confirmed for each bat in which a coronavirus was identified. A fragment of approximately 800 base pairs $(\mathrm{bp})$ of the mitochondrial cytochrome $\mathrm{b}(\mathrm{CytB})$ region was amplified using previously described primers to identify mammal species including bats, Cytb-L14724 (forward) and Cytb-H15506 (reverse), [45]. However, the forward primer was replaced by a newly designed primer Cytb-L1 5' ATG ACC AAC ATC CGA AAA TCN CAC-3' or Cytb-L2 5' - ATY TCY TCM TGA TGA AAY TTY GGM T- $3^{\prime}$ to increase PCR specificity for certain bat species. PCR products were diluted and directly sequenced with BigDye Terminator version 3.1 sequencing kit (Life Technologies, Courtaboeuf, France). Electrophoresis and data collection were processed on an Applied Biosystems 3500 Genetic Analyzer (Thermo Fisher Scientific, Foster City, CA, USA). Sequences from both strands were reconstituted using SeqMan Pro tool from the package DNAStar v17.0.2 (Lasergene, Madison, WI, USA). Sequences were pasted in the NCBI BLAST web interface (https://blast.ncbi.nlm.nih.gov/Blast.cgi) to identify the most similar bat species. For samples with no or low similarity $(<97 \%)$ hits with species in Genbank, a phylogenetic tree was constructed using maximum likelihood methods implemented in PhyML with reference sequences in order to obtain genus identification. The new sequences were deposited in the GenBank under accession numbers MT586773-MT586805. 


\subsection{RT-PCR Screening for Detection of Coronavirus RNA}

First, cDNA was synthesized from denatured RNA $\left(70{ }^{\circ} \mathrm{C}\right.$ for $\left.10 \mathrm{~min}\right)$ using a Reverse Transcription System kit with random primers (Promega, Madison, WI, USA), following manufacturer's instructions. PCR screening was done with a broadly reactive nested PCR approach in the highly conserved RdRp region. Our assay targeted a $440 \mathrm{bp}$ fragment using degenerate primers from a modified protocol described by Chu et al. (2011). In the first round, a 602 bp fragment was targeted following previously described PCR methods for which amplification conditions were slightly adapted [46]. Briefly, cDNA was amplified using the GoTaq Hot Start Master Mix PCR kit (Promega, Madison, WI, USA) as follows: 40 cycles of $92{ }^{\circ} \mathrm{C}$ for $30 \mathrm{~s}, 48^{\circ} \mathrm{C}$ for $30 \mathrm{~s}$ and $72{ }^{\circ} \mathrm{C}$ for $50 \mathrm{~s}$ for the first round of PCR. In the second round, a 440 bp product was amplified and cycling conditions were modified for the second round of PCR, using a touch-down technique to reduce nonspecific amplifications $\left(10\right.$ cycles of $92^{\circ} \mathrm{C}$ for $30 \mathrm{~s}, 53{ }^{\circ} \mathrm{C}$ for $30 \mathrm{~s}$ with $-0.5{ }^{\circ} \mathrm{C} / \mathrm{cycle}$ and $72{ }^{\circ} \mathrm{C}$ for $30 \mathrm{~s}, 35$ cycles of $92{ }^{\circ} \mathrm{C}$ for $30 \mathrm{~s}, 53{ }^{\circ} \mathrm{C}$ for $30 \mathrm{~s}$ and $72{ }^{\circ} \mathrm{C}$ for $30 \mathrm{~s}$ ). PCR products were first analyzed by agarose gel electrophoresis and positive amplicons were sequenced as indicated above and analyzed on the Applied Biosystems 3500 genetic analyzer platform. Sequences from both strands were reconstituted using SeqMan Pro tool from the package DNAStar v17.0.2 (Lasergene, Madison, WI, USA). Sequences were pasted in the NCBI BLAST web interface (https://blast.ncbi.nlm.nih.gov/Blast.cgi) to identify similar coronavirus sequences. The PCR assay was first tested on six nasopharyngeal swabs from patients positive for SARS-CoV-2, which are anonymous and untraceable diagnostic leftover samples, kindly provided by the Virology department of Montpellier University Hospital in March 2020. Amplification products and sequences were obtained, demonstrating that the assay is also able to detect the novel SARS-CoV-2 strain (data not shown).

\subsection{Phylogenetic Analyses}

The new sequences were aligned with representatives of alpha and beta-coronavirus sequences that have been reported mainly in Africa and elsewhere (Table S1). A multiple sequence alignment (MSA) was obtained by using MAFFT v7 (https://mafft.cbrc.jp/alignment/server/). The alignment was manually checked and end-trimmed to match with the newly obtained RdRp sequences and to remove the PCR primers sequences. The final MSA was used for maximum likelihood (ML) phylogenetic analysis with GTR $+\mathrm{F}+\mathrm{I}+4 \Gamma$ as the best-fit model of nucleotide substitution according to BIC and 1000 bootstrap resampling by using IQ-Tree server (http://iqtree.cibiv.univie.aC.at) [47,48]. Consensus trees were edited with FigTree v1.4.4. The new sequences were deposited in GenBank under accession numbers MT586830-MT586867.

\subsection{Statistical Analyse}

To explore the impact of age, sex and environment of the collected samples on the detection of coronavirus RNA, we performed Kruskal-Wallis test on bat field data. Significant results were considered for a $p$-value of $<0.05$.

\section{Results}

\subsection{Bat Species and Sampling}

Samples from a total of 319 wild bats, captured at 14 sites in seven different prefectures in Guinea, were studied (Figure 1, Table 1). Bats were captured in different ecological settings including the following environments: villages (38.6\%), forest sites (30.1\%), urban sites $(23.2 \%)$, plantations $(4.1 \%)$ and diverse other settings for the remainder (4.1\%). Species identification was confirmed by CytB sequence analysis on a total of $171(53.6 \%)$ bats to confirm at least one sample per sampling date, per capture method and per morphologic description at each site. Species identification was then extrapolated for the remaining samples by combining molecular and field data. For certain insectivorous bats (Molossidae, Rhinolophidae, Hipposideridae and Nycteridae) identification was 
only possible at the genus level, mostly due to the lack of reference sequences in Genbank. Because discrimination between Epomophorus gambiensis and Micropteropus pusillus was not possible based on CytB sequences only, we used morphologic details on forearm and weight measurements to discriminate the species for 93 bats, as previously documented by others [49]. Details on bat families, genera and species are shown in Table 2. We collected samples from $274(85.9 \%)$ frugivorous bats (Pteropodidae family) representing at least eight species and $45(14.1 \%)$ insectivorous bats from five families and at least six genera. Overall, $195(61.1 \%)$ bats were female, $121(37.9 \%)$ were male and for three $(1.0 \%)$ sex classification was not available. The vast majority were adults (300; $94.1 \%), 11(3.4 \%)$ were juveniles and for eight bats $(2.5 \%)$, age could not be identified, or information was not recorded.

Table 1. Number of bat samples collected at each study site in the different prefectures in Guinea.

\begin{tabular}{ccc}
\hline Prefecture & Site & Number \\
\hline Conakry & CN & 59 \\
& Subtotal & 59 \\
\hline Gueckedou & GK & 6 \\
& TM & 41 \\
& Subtotal & 47 \\
\hline Kankan & BN & 8 \\
& KK & 12 \\
Kindia & Subtotal & 20 \\
& KN & 13 \\
& MO & 54 \\
& SG & 35 \\
Koundara & Subtotal & 102 \\
& GN & 35 \\
& SA & 15 \\
& YK & 6 \\
& Subtotal & 56 \\
\hline Macenta & MA & 9 \\
& Subtotal & 9 \\
\hline Mamou & KR & 15 \\
& OK & 11 \\
& Subtotal & 26 \\
\hline Total & & 319 \\
\hline
\end{tabular}

Sites are indicated with a two-letter code as in Figure 1. Sites are abbreviated as follows: $\mathrm{CN}-$ Conakry; KN—Kindia; MO-Madina Oula; SG—Souguéta; KK—Kankan; BN—Baté-Nafadji; TM-Termessadou-Dibo; GK—Tékoulo; GN-Guingan; SA—Sareboido; YK-Youkounkoun; KR-Konkouré; OK-Ouré-Kaba; MA-Macenta. 
Table 2. Number and percentage of samples positive for coronavirus RNA in different bat families and species collected in each site.

\begin{tabular}{|c|c|c|c|c|c|c|c|c|c|c|c|c|c|c|c|c|}
\hline \multirow{2}{*}{$\begin{array}{l}\text { Family } \\
\text { Species }\end{array}$} & \multicolumn{2}{|c|}{ Conakry } & \multicolumn{2}{|c|}{ Kankan } & \multicolumn{2}{|c|}{ Kindia } & \multicolumn{2}{|c|}{ Koundara } & \multicolumn{2}{|c|}{ Gueckedou } & \multicolumn{2}{|c|}{ Macenta } & \multicolumn{2}{|c|}{ Mamou } & \multirow[b]{2}{*}{ Total } & \multirow[b]{2}{*}{$\%$ pos } \\
\hline & $\mathrm{CN}$ & BN & KK & KN & MO & SG & YK & SA & GN & GK & TM & MA & OK & KR & & \\
\hline \multicolumn{17}{|c|}{ Insectivorous Bats } \\
\hline Hipposideridae & $0 / 1$ & $1 / 4$ & $0 / 1$ & $6 / 13$ & $0 / 1$ & - & $0 / 1$ & - & - & - & - & - & - & - & $7 / 21$ & $33.3 \%$ \\
\hline Hipposideros sp. & $0 / 1$ & $1 / 4$ & $0 / 1$ & $6 / 13$ & $0 / 1$ & - & $0 / 1$ & - & - & - & - & - & - & - & $7 / 21$ & $33.3 \%$ \\
\hline Molossidae & - & - & - & - & $0 / 3$ & - & - & - & $0 / 10$ & - & - & - & - & - & $0 / 13$ & $0.0 \%$ \\
\hline Chaerephon sp. & - & - & - & - & $0 / 3$ & - & - & - & - & - & - & - & - & - & $0 / 3$ & $0.0 \%$ \\
\hline Mops condylurus & - & - & - & - & - & - & - & - & $0 / 10$ & - & - & - & - & - & $0 / 10$ & $0.0 \%$ \\
\hline Nycteridae & - & $1 / 2$ & - & - & - & - & - & - & $0 / 1$ & - & - & - & - & - & $1 / 3$ & $33.3 \%$ \\
\hline Nycteris sp. & - & $1 / 2$ & - & - & - & - & - & - & $0 / 1$ & - & - & - & - & - & $1 / 3$ & $33.3 \%$ \\
\hline Rhinolophidae & - & - & $2 / 5$ & - & - & - & - & - & - & - & - & - & - & - & $2 / 5$ & $40.0 \%$ \\
\hline Rhinolophus sp. & - & - & $2 / 5$ & - & - & - & - & - & - & - & - & - & - & - & $2 / 5$ & $40.0 \%$ \\
\hline Vespertilionidae & - & - & - & - & $0 / 2$ & - & - & - & $0 / 1$ & - & - & - & - & - & $0 / 3$ & $0.0 \%$ \\
\hline Scotophilus leucogaster & - & - & - & - & $0 / 2$ & - & - & - & $0 / 1$ & - & - & - & - & - & $0 / 3$ & $0.0 \%$ \\
\hline \multicolumn{17}{|c|}{ Fruit Bats } \\
\hline Pteropodidae & $6 / 58$ & $0 / 2$ & $0 / 6$ & - & $2 / 48$ & $2 / 35$ & $1 / 5$ & $1 / 15$ & $3 / 23$ & $1 / 6$ & $6 / 41$ & $2 / 9$ & $0 / 11$ & $1 / 15$ & $25 / 274$ & $9.1 \%$ \\
\hline Eidolon helvum & $3 / 6$ & - & - & - & - & - & - & $0 / 1$ & - & - & - & $1 / 2$ & - & - & $4 / 9$ & $44.4 \%$ \\
\hline Epomophorus gambianus & $3 / 48$ & $0 / 2$ & $0 / 5$ & - & $0 / 2$ & - & $1 / 3$ & $1 / 14$ & $0 / 2$ & - & - & - & $0 / 11$ & - & $5 / 87$ & $5.7 \%$ \\
\hline Epomops buettikoferi & - & - & - & - & - & - & - & - & - & $0 / 3$ & - & - & - & - & $0 / 3$ & $0.0 \%$ \\
\hline Hypsignathus monstrosus & - & - & - & - & - & - & - & - & - & $0 / 1$ & - & $0 / 5$ & - & - & $0 / 6$ & $0.0 \%$ \\
\hline Lissonycteris angolensis & - & - & - & - & $0 / 8$ & $0 / 6$ & - & - & $2 / 13$ & - & - & - & - & $1 / 15$ & $3 / 42$ & $7.1 \%$ \\
\hline Micropteropus pusillus & $0 / 4$ & - & $0 / 1$ & - & - & - & - & - & $0 / 1$ & - & - & - & - & - & $0 / 6$ & $0.0 \%$ \\
\hline Nanonycteris veldkampii & - & - & - & - & - & - & - & - & - & $1 / 1$ & - & - & - & - & $1 / 1$ & $100 \%$ \\
\hline Rousettus aegyptiacus & - & - & - & - & $2 / 38$ & $2 / 29$ & $0 / 2$ & - & $1 / 7$ & $0 / 1$ & $6 / 41$ & $1 / 2$ & - & - & $12 / 120$ & $10.0 \%$ \\
\hline Total & $6 / 59$ & $2 / 8$ & $2 / 12$ & $6 / 13$ & $2 / 54$ & $2 / 35$ & $1 / 6$ & $1 / 15$ & $3 / 35$ & $1 / 6$ & $6 / 41$ & 2/9 & $0 / 11$ & $1 / 15$ & $35 / 319$ & $11.0 \%$ \\
\hline$\%$ pos per site & $10.2 \%$ & $25.0 \%$ & $16.7 \%$ & $46.2 \%$ & $3.7 \%$ & $5.7 \%$ & $16.7 \%$ & $6.7 \%$ & $8.6 \%$ & $16.7 \%$ & $14.6 \%$ & $22.2 \%$ & $0.0 \%$ & $6.7 \%$ & & \\
\hline
\end{tabular}

CN-Conakry; KN-Kindia; MO—Madina Oula; SG—Souguéta; KK-Kankan; BN-Baté-Nafadji; TM-Termessadou-Dibo; GK-Tékoulo; GN-Guingan; SA-Sareboido;

YK-Youkounkoun; KR—Konkouré; OK—Ouré-Kaba; MA—Macenta.; '-' —not applicable because this species was not captured at that site. 


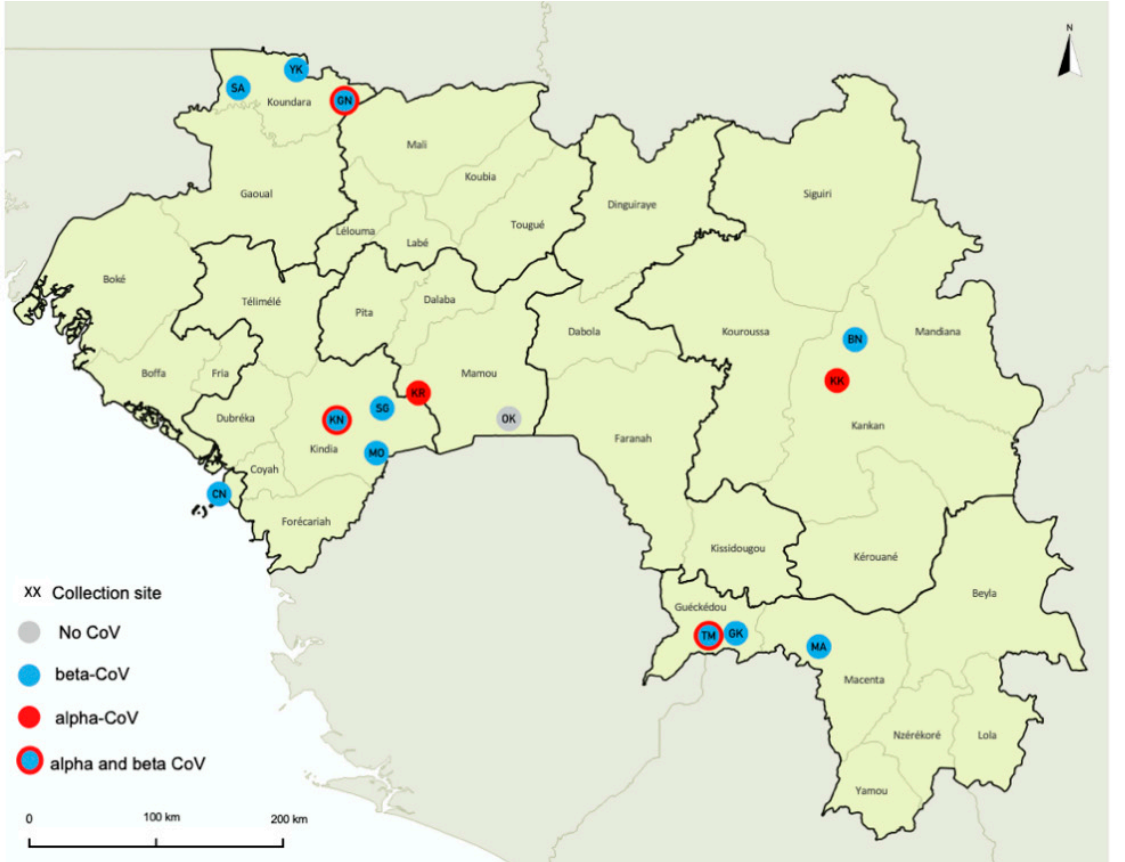

Figure 1. Bat collection sites in Guinea. Sites where samples from bat were collected are highlighted with circles on the map as follows: gray indicates site where no coronavirus $(\mathrm{CoV})$ was detected; red, sites where alphacoronavirus ( $\alpha-\mathrm{CoVs})$ were detected; blue, sites where betacoronavirus $(\beta-\mathrm{CoV})$ were detected, blue and red, sites where both $\alpha-\mathrm{CoVs}$ and $\beta-\mathrm{CoVs}$ were detected. Sites are abbreviated as follows: for the prefecture of Conakry: $\mathrm{CN}-$ Conakry; for the prefecture of Kindia: KN—Kindia; MO_-Madina Oula; SG—Souguéta; for the prefecture of Kankan: KK—Kankan; BN—Baté-Nafadji; for the prefecture of Gueckedou: TM-Termessadou-Dibo; GK-Tékoulo; for the prefecture of Koundara: GN-Guingan; SA—Sareboido; YK-Youkounkoun; for the prefecture of Mamou: KR-Konkouré; OK-Ouré-Kaba; and for the prefecture of Macenta: MA-Macenta.

\subsection{PCR Screening and Presence of $\alpha$ and $\beta$ Coronaviruses}

We screened a total of 634 samples from 319 bats by RT-PCR for the presence of coronavirus RNA: for $286(89.7 \%)$ bats oral and rectal swabs were tested, $19(6.6 \%)$ bats were tested using oral swabs and fecal samples, for five (1.6\%) oral and rectal swabs and feces, for two and seven bats only rectal or oral swabs were tested, respectively. A total of 38 samples from 35 of the 319 tested bats (11\%), were positive for the presence of CoVs; five in oral swabs only, 20 in rectal swabs only, seven in feces only, one in both feces and oral swab, two in rectal and oral swabs (Table 3). The rate of positivity varied according to the sample type; the proportion of positive samples was $7.5 \%(22 / 293)$ in rectal swabs, $2.5 \%(8 / 317)$ in oral swabs and $33.3 \%(8 / 24)$ in fresh fecal samples. Among the three bats that were positive in two different samples, two were infected with the same virus in the rectal and oral swab or in feces and oral swab, but for one bat, an $\alpha-\mathrm{CoV}$ and a $\beta-\mathrm{CoV}$ were detected in oral and rectal swab, respectively.

We confirmed the presence of CoVs in 10/45 (22.2\%) insectivorous bats from three species belonging to three families, i.e., Hipposideridae $(33.3 \%, 7 / 21)$, Rhinolophidae $(40.0 \%, 2 / 5)$ and Nycteridae $(33.3 \%$, $1 / 3)$. Among the frugivorous bats, $25 / 274$ (9.1\%) tested positive and CoVs were detected in five species: 4/9 (44.4\%) Eidolon helvum, 12/120 (10.0\%) Rousettus aegyptiacus, 3/42 (7.1\%) Lissonycteris angolensis, 5/87 (5.7\%) Epomophorus gambianus and the single Nanonycteris sp. bat. CoVs were identified in all provinces and in almost all sites where bats were sampled in Guinea (Figure 1). Among the positive bats, $72 \%$ were sampled close to human habitats, $23 \%$ in urban areas and $49 \%$ in villages. No significant impact of the age, sex of bats or environment on the presence of $\mathrm{CoV}$ was detected, using Kruskal-Wallis test $(p$-values $>0.05)$. 
Table 3. Detail on bat samples in which coronavirus sequences have been amplified. Sites are abbreviated as in Table 1.

\begin{tabular}{|c|c|c|c|c|c|c|c|c|c|}
\hline \multirow{2}{*}{ Sample } & \multirow{2}{*}{ Collection Date } & \multirow{2}{*}{ Prefecture } & \multirow{2}{*}{ Site } & \multirow{2}{*}{ Environment } & \multirow{2}{*}{ Species } & \multicolumn{3}{|c|}{ Type of Sample } & \multirow{2}{*}{ Accession Number } \\
\hline & & & & & & Rectal Swab & Feces & Oral Swab & \\
\hline CCGU00021 & 18 February 2016 & Conakry & $\mathrm{CN}$ & city garden & Epomophorus gambianus & $\beta-\mathrm{CoV}$ & na & - & MT586830 \\
\hline CCGU00033 & 21 February 2016 & Conakry & $\mathrm{CN}$ & city garden & Epomophorus gambianus & $\beta-\mathrm{CoV}$ & na & - & MT586831 \\
\hline CCGU00035 & 21 February 2016 & Conakry & $\mathrm{CN}$ & city garden & Epomophorus gambianus & - & $\beta-\mathrm{CoV}$ & - & MT586832 \\
\hline CCGU00039 & 20 April 2016 & Conakry & $\mathrm{CN}$ & city garden & Eidolon helvum & $\beta-\mathrm{CoV}$ & na & - & MT586833 \\
\hline CCGU00040 & 20 April 2016 & Conakry & $\mathrm{CN}$ & city garden & Eidolon helvum & $\beta-\mathrm{CoV}$ & na & - & MT586834 \\
\hline CCGU00041 & 20 April 2016 & Conakry & $\mathrm{CN}$ & city garden & Eidolon helvum & $\beta-\mathrm{CoV}$ & na & - & MT586835 \\
\hline CCGU00081 & 31 May 2016 & Kindia & $\mathrm{KN}$ & cave/village & Hipposideros ruber & na & $\alpha-\mathrm{CoV}$ & - & MT586836 \\
\hline CCGU00082 & 31 May 2016 & Kindia & $\mathrm{KN}$ & cave/village & Hipposideros ruber & $\alpha-\mathrm{CoV}$ & na & - & MT586837 \\
\hline CCGU00085 $^{1}$ & 31 May 2016 & Kindia & $\mathrm{KN}$ & cave/village & Hipposideros ruber & na & $\alpha-\mathrm{CoV}$ & $\alpha-\mathrm{CoV}$ & MT586838; MT586839 \\
\hline CCGU00086 & 31 May 2016 & Kindia & $\mathrm{KN}$ & cave/village & Hipposideros ruber & na & $\beta-\mathrm{CoV}$ & - & MT586840 \\
\hline CCGU00087 $^{1}$ & 31 May 2016 & Kindia & $\mathrm{KN}$ & cave/village & Hipposideros ruber & $\alpha-\mathrm{CoV}$ & na & $\alpha-\mathrm{CoV}$ & MT58684; MT586842 \\
\hline CCGU00090 & 31 May 2016 & Kindia & $\mathrm{KN}$ & cave/village & Hipposideros ruber & $\alpha-\mathrm{CoV}$ & na & - & MT586843 \\
\hline CCGU00102 & 21 July 2016 & Koundara & GN & cave/village & Lissonycteris angolensis & $\beta-\mathrm{CoV}$ & na & - & MT586844 \\
\hline CCGU00104 & 21 July 2016 & Koundara & GN & cave/village & Lissonycteris angolensis & $\beta-\mathrm{CoV}$ & na & - & MT586845 \\
\hline CCGU00115 & 22 July 2016 & Koundara & GN & village & Rousettus aegyptiacus & - & na & $\alpha-\mathrm{CoV}$ & MT586846 \\
\hline CCGU00137 & 24 July 2016 & Koundara & YK & village & Epomophorus gambianus & $\beta-\mathrm{CoV}$ & na & - & MT586847 \\
\hline CCGU00142 & 27 July 2016 & Koundara & SA & village & Epomophorus gambianus & $\beta-\mathrm{CoV}$ & na & - & MT586848 \\
\hline CCGU00168 & 22 September 2016 & Kankan & KK & cave/forest & Rhinolophus darlingi & na & $\alpha-\mathrm{CoV}$ & - & MT586849 \\
\hline CCGU00200 & 25 September 2016 & Kankan & KK & cave/forest & Rhinolophus darlingi & na & $\alpha-\mathrm{CoV}$ & - & MT586850 \\
\hline CCGU00235 & 28 September 2016 & Kankan & $\mathrm{BN}$ & cave & Nycteris macrotis & na & $\beta-\mathrm{CoV}$ & - & MT586851 \\
\hline CCGU00269 & 29 September 2016 & Kankan & $\mathrm{BN}$ & cave & Hipposideros ruber & na & $\beta-\mathrm{CoV}$ & - & MT586852 \\
\hline CCGU00316 & 27 October 2016 & Kindia & $\mathrm{MO}$ & cave/forest & Rousettus aegyptiacus & $\beta-\mathrm{CoV}$ & na & - & MT586853 \\
\hline CCGU00337 & 29 October 2016 & Kindia & $\mathrm{MO}$ & plantation & Rousettus aegyptiacus & $\beta-\mathrm{CoV}$ & na & - & MT586854 \\
\hline CCGU00399 & 2 November 2016 & Kindia & SG & cave/forest & Rousettus aegyptiacus & $\beta-\mathrm{CoV}$ & na & - & MT586855 \\
\hline CCGU00424 & 3 November 2016 & Kindia & SG & forest & Rousettus aegyptiacus & $\beta-\mathrm{CoV}$ & na & - & MT586856 \\
\hline CCGU00445 & 5 December 2016 & Gueckedou & TM & cave/forest & Rousettus aegyptiacus & - & na & $\alpha-\mathrm{CoV}$ & MT586857 \\
\hline CCGU00453 & 6 December 2016 & Gueckedou & $\mathrm{TM}$ & village & Rousettus aegyptiacus & $\beta-\mathrm{CoV}$ & na & $\alpha-\mathrm{CoV}$ & MT586858-586859 \\
\hline CCGU00458 & 6 December 2016 & Gueckedou & TM & village & Rousettus aegyptiacus & - & na & $\alpha-\mathrm{CoV}$ & MT586860 \\
\hline CCGU00467 & 7 December 2016 & Gueckedou & $\mathrm{TM}$ & village & Rousettus aegyptiacus & - & na & $\alpha-\mathrm{CoV}$ & MT586861 \\
\hline CCGU00477 & 7 December 2016 & Gueckedou & $\mathrm{TM}$ & village & Rousettus aegyptiacus & $\alpha-\mathrm{CoV}$ & na & - & MT586862 \\
\hline CCGU00481 & 7 December 2016 & Gueckedou & $\mathrm{TM}$ & village & Rousettus aegyptiacus & - & na & $\alpha-\mathrm{CoV}$ & MT586863 \\
\hline CCGU00489 & 10 December 2016 & Gueckedou & GK & village & Nanonycteris veldkampii & $\beta-\mathrm{CoV}$ & na & - & MT586864 \\
\hline CCGU00499 & 12 December 2016 & Macenta & MA & city & Rousettus aegyptiacus & $\beta-\mathrm{CoV}$ & na & - & MT586865 \\
\hline CCGU00502 & 12 December 2016 & Macenta & MA & city & Eidolon helvum & $\beta-\mathrm{CoV}$ & na & - & MT586866 \\
\hline CCGU00550 & 9 January 2017 & Mamou & $\mathrm{KR}$ & cave/forest & Lissonycteris angolensis & $\alpha-\mathrm{CoV}$ & na & - & MT586867 \\
\hline
\end{tabular}

${ }^{1}$ identical sequences in both swabs; $\alpha$-CoV—alphacoronavirus; $\beta$-CoV—-betacoronavirus; na—no sample; -: PCR-negative sample. 
We identified thus $38 \mathrm{CoV}$ sequences, 15 sequences belonging to the $\alpha$-CoV genus and 23 to the $\beta-\mathrm{CoV}$ genus, the latter known to harbor five HCoVs, i.e., HCoV-OC43, HCoV-HKU1 and the highly pathogenic SARS-CoV-1, MERS-CoV and the recently described SARS-CoV-2 from the ongoing COVID-19 pandemic. Of all, 14 bats were infected with $\alpha$-CoVs, 20 with $\beta$-CoV and one bat (R. aegyptiacus) was co-infected with both, as mentioned above. Among the $15 \alpha-\mathrm{CoVs}$, six were detected in oral swabs only, one in oral and rectal swabs, one in feces and oral swabs, four in rectal swabs and three in feces only. All $23 \beta$-CoVs were identified in rectal swabs or feces and not in oral swabs.

\subsection{Genetic Diversity of Bat Coronaviruses}

The phylogenetic analysis based on $374 \mathrm{bp}$ nucleotides of the new sequences and reference sequences is shown in Figure 2. High genetic diversity was observed among the newly identified $\alpha$ and $\beta$-CoVs. $\alpha$-CoVs were detected in $7 / 45$ (15.6\%) of insectivorous bats; five Hipposideros sp. and two Rhinolophus spp. (Figure 2A). All $\alpha-\mathrm{CoV}$ strains from Hipposideros bats in Guinea clustered with previously reported CoV sequences from bats from this genus in Zimbabwe, Gabon or Ghana and comprising also the HCoV-229E virus. The new $\alpha-\mathrm{CoV}$ strains from Rhinolophus bats fall in a cluster that groups sequences from other Rhinolophus bats captured in Mozambique and Kenya. Among frugivorous bats, 8/274 (2.9\%) were infected with $\alpha-\mathrm{CoV}$; seven $R$. aegyptiacus and one L. angolensis. $\alpha$-CoVs from $R$. aegyptiacus formed a separate lineage for which no close relatives (>90\% homology) were detected in Genbank. The new $\alpha-\mathrm{CoV}$ sequence from a frugivorous L. angolensis clustered with $\mathrm{CoV}$ sequences mainly obtained from insectivorous Molossidae bats from Cameroon, Tanzania, Southern Africa and the Western Indian ocean.

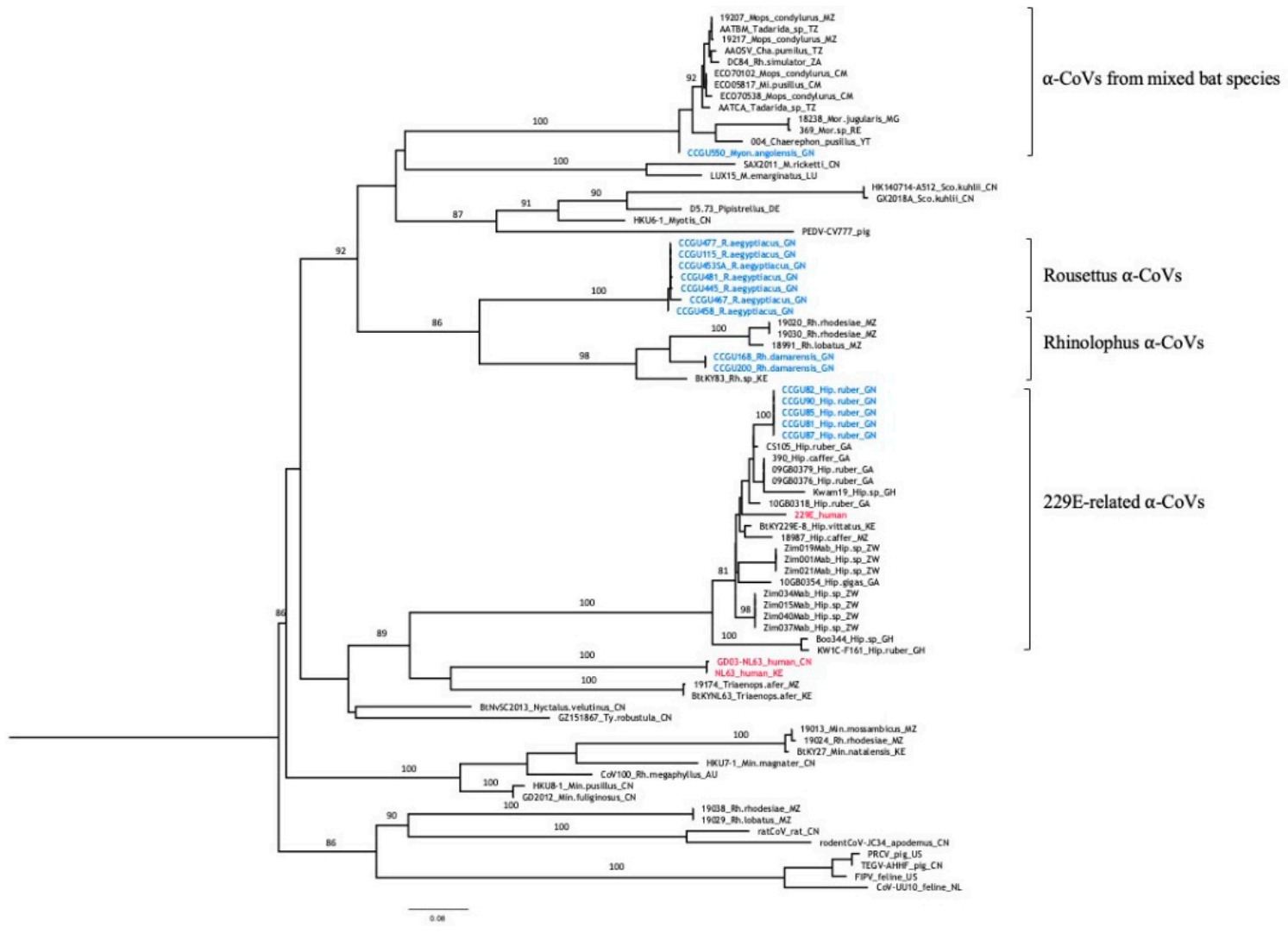

(a)

Figure 2. Cont. 


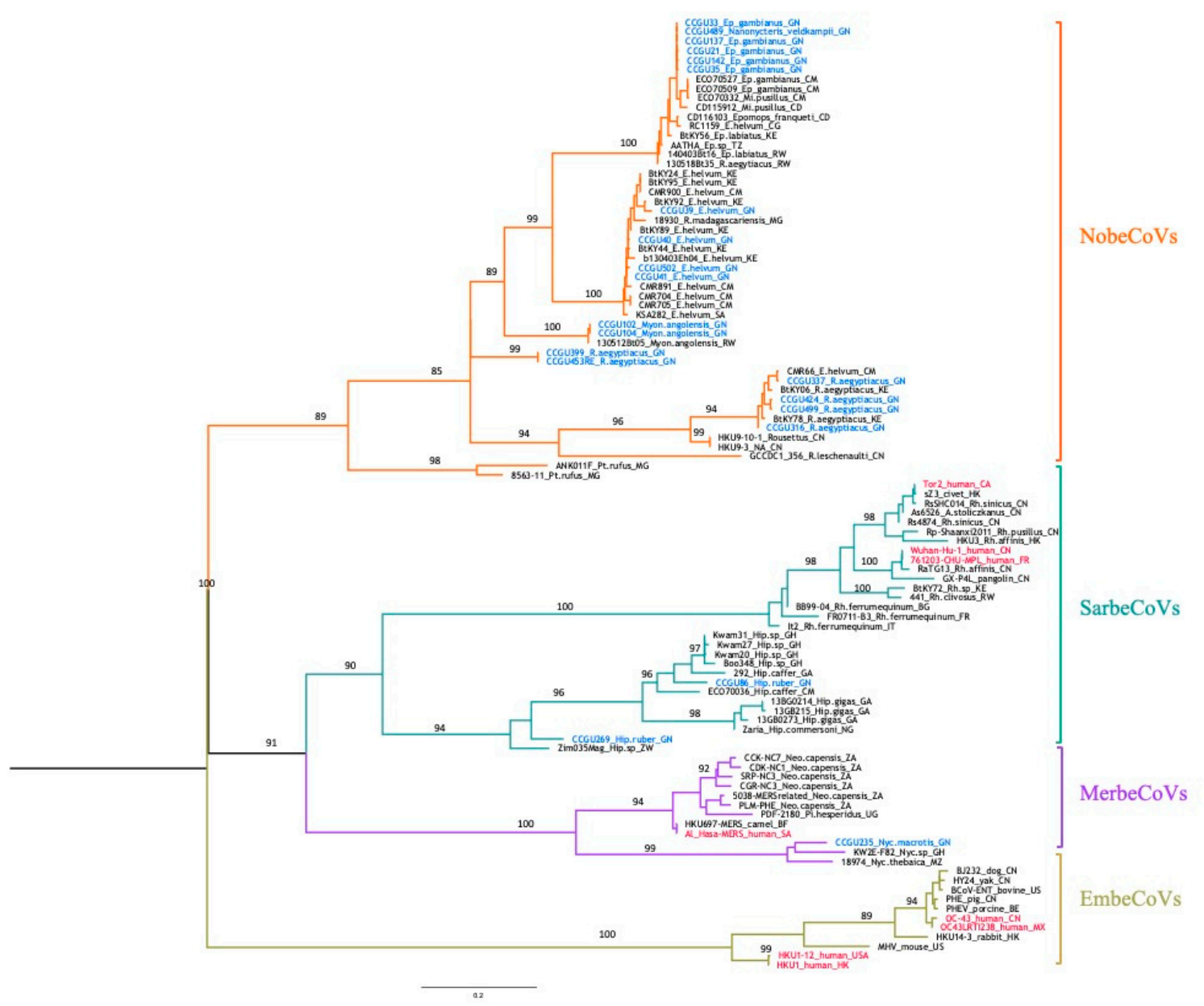

(b)

Figure 2. Maximum likelihood (ML) consensus trees derived from coronavirus sequences in the RNA-dependent RNA-polymerase partial nucleotide sequences (374 unambiguously aligned base pairs). (a) consensus tree derived from 78 alphacoronaviruses; (b) consensus tree derived from 102 betacoronaviruses. Phylogenetic tree analysis was performed using the GTR + F + I + 4 $\Gamma$ nucleotide substitution model and 1000 bootstrap resampling. Sequences in blue refer to the new bat CoVs detected in this study. Human CoVs are highlighted in red. Branch supports $>0.75$ are indicated on the trees. Trees were generated as indicated in Material and Methods and edited with increasing nodes and midpoint rooting in FigTree. Details on reference sequences are provided in Supplementary Table S1. Abbreviations of bat genera are as follows: Ep-Epomophorus; R-Rousettus; E-Eidolon; Myon—Lissonycteris (previously Myonycteris); Mi-Micropteropus; Nyc-Nycteris; Hip-Hipposideros; Rh-Rhinolophus; Neo-Neoromicia; Pt_Pteropus; A-Aselliscus; Pi-Pipistrellus; Min-Miniopterus; Mor-Mormopterus; ChA-Chaerephon; M-Myotis; Sco-Scotophilus.

$\beta$-CoVs were observed in 18/274 (6.6\%) frugivorous bats and 3/45 (4.4\%) insectivorous bats. None of the new viruses was closely related to the human $\beta$-CoVs (Figure $2 \mathrm{~B}$ ). Among $\beta$-CoVs, our sequences fell into three subgenera, recently named Sarbecovirus, Merbecovirus and Nobecovirus [50]. All the $18 \beta-\mathrm{CoV}$ sequences detected in fruit bats clustered in the NobeCoV subgenus comprising only $\mathrm{CoVs}$ from Pteropodid bats from various places in Asia and Africa (i.e., Kenya, Cameroon, Rwanda, Madagascar, Congo, Tanzania). New $\beta$-CoVs strains from E. helvum clustered with previously reported $\mathrm{CoV}$ strains form this species observed in bats from Cameroon, Kenya and even Saudi Arabia. However, a $\beta-\mathrm{CoV}$ from a Rousettus bat from Madagascar fell also in this clade. Similarly, the five new $\beta-\mathrm{CoV}$ strains from Epomophorus bats clustered with previously documented strains from this genus from other regions in Africa, but strains from other bat species like Micropteropus pusillus or Rousettus sp. 
from central and Eastern Africa were also observed in this clade. Interestingly, the new $\beta$-CoV from the Nanonycteris bat in Guinea fell in the same cluster. The new strains from Lissonycteris angolensis were closely related to a recently reported $\beta-\mathrm{CoV}$ from the same species in Rwanda. Among the new $\beta$-CoVs from Rousettus aegyptiacus, two strains formed a separate lineage with no close relatives $(>90 \%$ homology) in Genbank and the four remaining strains clustered with $\beta$-CoVs identified in Rousettus sp. from Cameroon or Kenya.

The $\beta$-CoVs observed in insectivorous bats belonged to two subgenera. The two $\beta-\mathrm{CoV}$ strains from Hipposideros bats belonged to the SarbeCoVs subgenus, that also harbor the human SARS-CoV strains as well as other closely related $\mathrm{CoVs}$ from insectivorous bats, civets and pangolins. Our sequences were highly diverse and fell in a clade grouping a wide diversity of CoVs, all from Hipposideros bats in diverse African countries. Finally, the new $\beta-\mathrm{CoV}$ strain from the Nycteris bat, trapped in a cave, belongs to the MerbeCoV genus which includes the CoVs responsible for the human Middle East respiratory syndrome and closely related $\mathrm{CoVs}$ detected in camels and Vespertilionidae bats (Pipistrellus sp. from China, Uganda and Neoromica sp. from South Africa). Our sequence clustered specifically in a distinct clade with other strains from Nycteris bats from Mozambique and Ghana that was basal to the MERS-CoV related viruses.

Overall, Rousettus and Hipposideros bats from our study are infected with at least three different CoVs (one $\alpha-\mathrm{CoV}$ and two $\beta-\mathrm{CoVs}$ ) and L. angolensis bats with $\alpha-\mathrm{CoV}$ and $\beta-\mathrm{CoVs}$.

\section{Discussion}

With the recent emergence of the COVID-19 pandemic caused by SARS-CoV-2 and the previous highly pathogenic SARS-CoV-1 and MERS-CoV outbreaks, it is important to better document the diversity and evolution of coronaviruses, particularly in regions at high-risk for emergence of infectious diseases of zoonotic origin. All CoVs in humans have a zoonotic origin with a direct or indirect link with bat CoVs. Here we documented for the first time the presence and genetic diversity of alpha and beta coronaviruses in bats in Guinea, West Africa, where contacts between humans and bats are frequent. In this pilot study, we analyzed more than 300 bats from at least eight frugivorous and six insectivorous species, collected at 14 different areas in seven prefectures across the country. We detected and characterized coronaviruses in $11 \%$ of the bats, at almost all sites and observed a wide diversity of $\alpha$ and $\beta$-CoVs with potential new viral lineages. Some strains belonged to the subgenera of MerbeCoV and SarbeCoVs known to harbor highly pathogenic HCoVs like MERS-CoV and SARS-CoV, respectively. We also report for the first time, the presence of a coronavirus in a bat from the genus Nanonycteris.

The overall rate of $\mathrm{CoV}$ detection $(11 \%)$ in our study is consistent with the rates found in previous studies in Kenya and Mozambique [40,51], but infection rates in studies in central and southern Africa and the western Indian Ocean were generally lower [15,35,38-40,42,52]. Positivity rates of coronavirus detection can vary by species and season, therefore comparison between studies is limited. In Guinea, we also observed differences in positivity rates according to species. Although we tested only a few samples per species, high rates were observed in three insectivorous genera from three families (7/21 Hipposideros sp., 1/3 Nycteris sp. and 2/5 Rhinolophus sp.) and two frugivorous species (4/9 Eidolon helvum and 1/1 Nanonycteris sp.). However, it cannot be excluded that this could be related to the season when samples were collected, for example several studies have shown temporal variations of $\mathrm{CoV}$ infections associated with parturition [37,41,53-55]. Longer follow-up should be done on these bat species in Guinea to assess temporal dynamics of $\mathrm{CoV}$ infection. Most samples have been obtained in cities or villages close to human habitats, it is thus important to know whether exposure to bat CoVs vary during certain periods of the year. Differences in positivity rates can also be explained by the nature of samples that have been tested, for example in our study we observed higher rates in feces and rectal swabs than in saliva. This was also observed in other reports and confirms that coronaviruses are highly shed in the intestinal tract [56]. Therefore, non-invasive collection of fresh bat 
feces, under roosting or feeding sites, may be more efficient to study CoVs, especially for species that are difficult to access.

Phylogenetic analyses revealed a wide diversity of $\alpha$ and $\beta-\mathrm{CoVs}$ with potential examples of co-evolution between CoVs and their bat hosts and examples of host diversity within CoV lineages. The genetic diversity observed in our study is most likely associated with the high diversity of bat species tested, which is in accordance with previous findings [40]. It also confirms the observations from the large study on CoVs in more than 12,000 bats across Africa and Asia from Anthony et al. (2017) who demonstrated that increasing sampling efforts leads to increased identification of new lineages. Although we studied only very few samples from Hipposideros bats, we did not only find a high infection rate $(7 / 21,33 \%)$, but observed also a high genetic diversity among their CoVs in accordance with most previous studies on Hipposideros species in Africa [15,34,35,39-42]. The human 229E $\alpha$-CoV falls in a clade of bat CoVs that is widely present in Hipposideros bats from Kenya, Zimbabwe, Mozambique, Gabon, Ghana and also in our study in Guinea. Hipposiderids roost in hollow trees, small caves and abandoned buildings, and indirect and direct exposure to infected bats and to the wide diversity of CoVs is thus very likely $[57,58]$. Moreover, the $\beta-\mathrm{CoVs}$ observed in Hipposideros bats belong to the SarbeCoV subgenus where they form a sister-clade to the clade of human and animal CoVs related to SARS-CoV-1 and -2. Within this viral clade, the genetic diversity is also very high, and viruses from this clade are present in Hipposideros species across Africa [15,35,39,41,59]. CoVs have also been described in Hipposideros bats in China and Thailand, suggesting a potential new clade $[55,60,61]$. The $\beta-\mathrm{CoV}$ observed in the Nycteris bat from Guinea falls with other CoVs from Nycteris bats in the MerbeCoV subgenus, forming a sister clade to the MERS-CoV related viruses from humans and animals. This clade is also widespread in Nycteris species across Africa $[37,40]$. All $\beta$-CoVs from frugivorous bats fall within the NobeCoV subgenus, in which for certain species potential new viral lineages are seen. However, this could be related to the low number of $\mathrm{CoVs}$ available among GenBank references. For $\alpha$-CoVs we also observed mainly association between $\mathrm{CoVs}$ and their bat hosts, except for $\alpha-\mathrm{CoV}$ virus identified in the frugivorous L. angolensis bat (CCGU550) clustering with $\alpha$-CoVs from insectivorous bats.

As in other studies, we also showed that the same bat species can be infected with different $\alpha$ and/or $\beta-\mathrm{CoV}$ lineages and species; this was seen in L. angolensis, R. aegyptiacus and Hipposideros sp. bats $[15,34,39,51,56,62]$. We observed a co-infection in a single Rousettus aegyptiacus bat with an alpha and betacoronavirus. Co-infections have been previously reported among insectivorous bats in Asia, but not yet in Africa [61-63].

We confirm that different viruses co-circulate in the same species and that certain viral strains may be maintained in more than one host and that cross-species transmission may occur, as previously reported $[34,64]$. These results are important because viral sharing and cross-species transmission may lead to recombination events and the emergence of novel bat coronaviruses or novel coronaviruses in other mammal species naturally infected with CoVs [64,65]. Recent studies demonstrated that frequent cross-species transmission seem to explain the evolutionary history of CoVs rather than co-divergence $[56,66]$. Moreover, viruses with a higher taxonomically and ecologically diverse host range seem to be more likely to adapt to humans and spread on a broad geographic scale and thus with a higher pandemic potential [65].

With this study in Guinea, we brought additional knowledge on coronaviruses in bats in Africa and especially in West Africa where only information was available for bats from Ghana and for small numbers of bats and species in Senegal and Nigeria $[15,35,37,59]$. The fact that we observed a high genetic diversity with potential new viral variants illustrates clearly that knowledge on bat coronaviruses is still incomplete and that more bat CoVs will be discovered as sampling efforts will increase. Anthony et al. (2017) even estimate that more than 3000 bat CoVs circulate in the more than 1400 known bat species [56]. Given the impact of zoonotic transmissions from CoVs to humans, it is important to document the CoVs that circulate in bats, but also in other wildlife species because for certain $\mathrm{HCoVs}$, intermediate hosts were involved. For example, the closest relative to SARS-CoV-2 
is the SARSr-Ra-BatCoV-RaTG13 from Rhinolophus bats from China, sharing more than $96 \%$ identity at the whole-genome level, but the receptor binding domain (RBD) exhibits stronger similarity to $\mathrm{CoVs}$ identified in pangolins, suggesting recombination [24,25]. However, it cannot be excluded that a not yet identified $\mathrm{CoV}$ in bats or another animal species is at the origin of the current SARS-CoV-2 epidemic. A prerequisite for cross-species transmission is compatibility between virus and human receptors, therefore future studies should not only focus on partial RdRp sequences but should thus also include characterization of the RBD of CoVs. In addition, as reminder, our findings are based on a small fragment of the RdRp gene, which is a highly conserved region. Therefore, complete genome sequencing and analysis of some key genes such as the Spike and ORF8 genes that have been shown to be hypervariable, should allow to assess recombination events [61,64]. This will bring additional data to retrieve phylogenetic and temporal relationships between these bat CoVs and other pathogenic strains and thus give us more insight into their zoonotic potential.

\section{Conclusions}

In this pilot study, we have demonstrated high rates and important genetic diversity of CoVs in frugivorous and insectivorous bats in Guinea. More studies are needed on CoVs in bats and wildlife in Guinea, but also in other geographic areas of Africa. This will certainly lead to the identification of more novel $\mathrm{CoV}$ species and maybe also new genera. Although we now have data for several thousands of bats worldwide, this still remains relatively small given the high numbers of bats that constitute colonies and the high number of bat species worldwide [67]. Future studies should focus on areas and species where contacts between humans are frequent or could become frequent due to environmental and climate changes. The high genetic diversity and complex evolutionary history of co-evolution, host switching, and recombination illustrates the complexity to track the animal reservoir of CoVs and to predict the areas at highest risk and species infected with CoVs with higher adaptive probability to infect humans. Efforts must continue not only on bats, but also on other animals to elucidate where CoVs circulate in wildlife and to clarify the role of intermediate species.

Supplementary Materials: The following are available online at http://www.mdpi.com/1999-4915/12/8/855/s1, Table S1: Details on coronavirus reference sequences used in phylogenetic tree analysis.

Author Contributions: Conceptualization, A.K.K., A.A. and M.P. (Martine Peeters); methodology and formal analysis, A.L., N.V., A.A., A.K.K., M.P. (Martine Peeters); investigation; A.K.K., R.D., S.G., A.K.S., M.P. (Moriba Povogui), J.K., J.-L.M., H.D.N., A.L., N.V., G.T., A.E., R.R., A.N., A.A.; writing-original draft preparation: A.L., N.V., A.K.K., M.P. (Martine Peeters); writing-review and editing: A.A., G.T., A.T., H.D.N., E.D. and V.F.; supervision; M.P. (Martine Peeters), A.A., A.K.K.; funding acquisition: A.A., M.P. (Martine Peeters) and E.D. All authors have read and agreed to the published version of the manuscript.

Funding: This work was supported in part by grants from Institut National de la Santé et de la Recherche Médicale (INSERM)/the Ebola Task Force/REACTing, EBO-SURSY project funded by the European Union, Institut de Recherche pour le Développement (IRD) and Agence Nationale de Recherches sur le SIDA (Grant Number ANRS-COVID10). A.K.K. was supported by fellowships from IRD and the University of Montpellier (MUSE, ANR-16-IDEX-0006). Raisa Raulino was supported by a PhD grant from INSERM and University of Montpellier and Antoine Nkuba was supported by a doctoral fellowship from the French foreign office.

Acknowledgments: We thank the Ministries of Health, Environment and the National Ethics committee from Guinea, for permission to perform this study. We thank all the field staff from Guinea for the collection of bat samples. We also thank Thomas Lemarcis for assistance in molecular identification of bat species. We thank Seny Mane, National Director of Veterinary Services of Guinea and current technical advisor to the Ministry of Livestock and Animal Production for his involvement and support in the implementation of the project. We thank Daouda Bangoura, former National Director of Guinean Veterinary Services and OIE focal point in Guinea and Colonel Bhoye Sow, Deputy Director General of the Guinean Office of Parks and Reserves for their constant support to the project and the facilitation of field missions.

Conflicts of Interest: The authors declare no conflict of interest.

\section{References}

1. Jones, K.E.; Patel, N.G.; Levy, M.A.; Storeygard, A.; Balk, D.; Gittleman, J.L.; Daszak, P. Global trends in emerging infectious diseases. Nature 2008, 451, 990-993. [CrossRef] 
2. Wolfe, N.D.; Dunavan, C.P.; Diamond, J. Origins of major human infectious diseases. Nature 2007, 447, 279-283. [CrossRef]

3. Cunningham, A.A.; Daszak, P.; Wood, J.L.N. One Health, emerging infectious diseases and wildlife: Two decades of progress? Philos. Trans. R. Soc. B Biol. Sci. 2017, 372, 20160167. [CrossRef]

4. Altizer, S.; Ostfeld, R.S.; Johnson, P.T.J.; Kutz, S.; Harvell, C.D. Climate Change and Infectious Diseases: From Evidence to a Predictive Framework. Science 2013, 341, 514-519. [CrossRef] [PubMed]

5. World Health Organization. Coronavirus Disease (COVID-19) Situation Report 129; World Health Organization: Geneva, Switzerland, 2020. Available online: https://www.who.int/docs/default-source/coronaviruse/ situation-reports/20200528-covid-19-sitrep-129.pdf?sfvrsn=5b154880_2 (accessed on 29 May 2020).

6. Ye, Z.-W.; Yuan, S.; Yuen, K.-S.; Fung, S.-Y.; Chan, C.-P.; Jin, D.-Y. Zoonotic origins of human coronaviruses. Int. J. Biol. Sci. 2020, 16, 1686-1697. [CrossRef] [PubMed]

7. Su, S.; Wong, G.; Shi, W.; Liu, J.; Lai, A.C.K.; Zhou, J.; Liu, W.; Bi, Y.; Gao, G.F. epidemiology, genetic recombination, and pathogenesis of coronaviruses. Trends Microbiol. 2016, 24, 490-502. [CrossRef] [PubMed]

8. $\quad$ Peiris, J.S.M.; Yuen, K.Y.; Osterhaus, A.D.M.E.; Stöhr, K. The Severe Acute Respiratory Syndrome. N. Engl. J. Med. 2003, 349, 2431-2441. [CrossRef]

9. Peiris, J.S.M.; Lai, S.T.; Poon, L.L.M.; Guan, Y.; Yam, L.Y.C.; Lim, W.; Nicholls, J.; Yee, W.K.S.; Yan, W.W.; Cheung, M.T.; et al. Coronavirus as a possible cause of severe acute respiratory syndrome. Lancet 2003, 361, 1319-1325. [CrossRef]

10. Zaki, A.M.; van Boheemen, S.; Bestebroer, T.M.; Osterhaus, A.D.M.E.; Fouchier, R.A.M. Isolation of a novel coronavirus from a man with pneumonia in Saudi Arabia. N. Engl. J. Med. 2012, 367, 1814-1820. [CrossRef] [PubMed]

11. Zumla, A.; Hui, D.S.; Perlman, S. Middle East respiratory syndrome. Lancet 2015, 386, 995-1007. [CrossRef]

12. World Health Organization OMS. Coronavirus du Syndrome Respiratoire du Moyen-Orient (MERS-CoV)—Qatar. Available online: http://www.who.int/csr/don/12-march-2020-mers-qatar/fr/ (accessed on 27 May 2020).

13. He, X.; Lau, E.H.; Wu, P.; Deng, X.; Wang, J.; Hao, X.; Lau, Y.C.; Wong, J.Y.; Guan, Y.; Tan, X.; et al. Temporal dynamics in viral shedding and transmissibility of COVID-19. medRxiv 2020, 26, 672-675. [CrossRef] [PubMed]

14. Vijaykrishna, D.; Smith, G.J.D.; Zhang, J.X.; Peiris, J.S.M.; Chen, H.; Guan, Y. Evolutionary insights into the ecology of coronaviruses. J. Virol. 2007, 81, 4012-4020. [CrossRef] [PubMed]

15. Pfefferle, S.; Oppong, S.; Drexler, J.F.; Gloza-Rausch, F.; Ipsen, A.; Seebens, A.; Müller, M.A.; Annan, A.; Vallo, P.; Adu-Sarkodie, Y.; et al. Distant relatives of severe acute respiratory syndrome coronavirus and close relatives of human coronavirus 229E in Bats, Ghana. Emerg. Infect. Dis 2009, 15, 1377-1384. [CrossRef]

16. Huynh, J.; Li, S.; Yount, B.; Smith, A.; Sturges, L.; Olsen, J.C.; Nagel, J.; Johnson, J.B.; Agnihothram, S.; Gates, J.E.; et al. Evidence supporting a zoonotic origin of human coronavirus strain NL63. J. Virol. 2012, 86, 12816-12825. [CrossRef]

17. Corman, V.M.; Muth, D.; Niemeyer, D.; Drosten, C. Hosts and sources of endemic human coronaviruses. Adv. Virus Res. 2018, 100, 163-188. [CrossRef]

18. Guan, Y.; Zheng, B.J.; He, Y.Q.; Liu, X.L.; Zhuang, Z.X.; Cheung, C.L.; Luo, S.W.; Li, P.H.; Zhang, L.J.; Guan, Y.J.; et al. Isolation and characterization of viruses related to the SARS coronavirus from animals in southern China. Science 2003, 302, 276-278. [CrossRef] [PubMed]

19. Lau, S.K.P.; Woo, P.C.Y.; Li, K.S.M.; Huang, Y.; Tsoi, H.-W.; Wong, B.H.L.; Wong, S.S.Y.; Leung, S.-Y.; Chan, K.-H.; Yuen, K.-Y. Severe acute respiratory syndrome coronavirus-like virus in Chinese horseshoe bats. PNAS 2005, 102, 14040-14045. [CrossRef] [PubMed]

20. Li, W.; Shi, Z.; Yu, M.; Ren, W.; Smith, C.; Epstein, J.H.; Wang, H.; Crameri, G.; Hu, Z.; Zhang, H.; et al. Bats are natural reservoirs of SARS-Like coronaviruses. Science 2005, 310, 676-679. [CrossRef] [PubMed]

21. Chan, J.F.W.; Lau, S.K.P.; To, K.K.W.; Cheng, V.C.C.; Woo, P.C.Y.; Yuen, K.-Y. Middle East respiratory syndrome coronavirus: Another zoonotic betacoronavirus causing SARS-like disease. Clin. Microbiol. Rev. 2015, 28, 465-522. [CrossRef]

22. Luo, C.-M.; Wang, N.; Yang, X.-L.; Liu, H.-Z.; Zhang, W.; Li, B.; Hu, B.; Peng, C.; Geng, Q.-B.; Zhu, G.-J.; et al. Discovery of novel bat coronaviruses in south china that use the same receptor as middle east respiratory syndrome coronavirus. J. Virol. 2018, 92. [CrossRef] 
23. Corman, V.M.; Ithete, N.L.; Richards, L.R.; Schoeman, M.C.; Preiser, W.; Drosten, C.; Drexler, J.F. Rooting the phylogenetic tree of Middle East respiratory syndrome coronavirus by characterization of a conspecific virus from an African bat. J. Virol. 2014, 88, 11297-11303. [CrossRef]

24. Lam, T.T.-Y.; Shum, M.H.-H.; Zhu, H.-C.; Tong, Y.-G.; Ni, X.-B.; Liao, Y.-S.; Wei, W.; Cheung, W.Y.-M.; Li, W.-J.; Li, L.-F.; et al. Identifying SARS-CoV-2 related coronaviruses in Malayan pangolins. Nature 2020, 1-6. [CrossRef]

25. Zhou, P.; Yang, X.-L.; Wang, X.-G.; Hu, B.; Zhang, L.; Zhang, W.; Si, H.-R.; Zhu, Y.; Li, B.; Huang, C.-L.; et al. A pneumonia outbreak associated with a new coronavirus of probable bat origin. Nature 2020. [CrossRef]

26. Banerjee, A.; Kulcsar, K.; Misra, V.; Frieman, M.; Mossman, K. Bats and coronaviruses. Viruses 2019, $11,41$. [CrossRef]

27. Teeling, E.C.; Springer, M.S.; Madsen, O.; Bates, P.; O’brien, S.J.; Murphy, W.J. A molecular phylogeny for bats illuminates biogeography and the fossil record. Science 2005, 307, 580-584. [CrossRef]

28. Wolfe, N.D.; Daszak, P.; Kilpatrick, A.M.; Burke, D.S. Bushmeat hunting, deforestation, and prediction of zoonotic disease. Emerg. Infect. Dis. 2005, 11, 1822. [CrossRef] [PubMed]

29. Kamins, A.O.; Restif, O.; Ntiamoa-Baidu, Y.; Suu-Ire, R.; Hayman, D.T.S.; Cunningham, A.A.; Wood, J.L.N.; Rowcliffe, J.M. Uncovering the fruit bat bushmeat commodity chain and the true extent of fruit bat hunting in Ghana, West Africa. Biol. Conserv. 2011, 144, 3000-3008. [CrossRef]

30. Lee, T.M.; Sigouin, A.; Pinedo-Vasquez, M.; Nasi, R. The Harvest of Wildlife for Bushmeat and Traditional Medicine in East, South and Southeast Asia: Current Knowledge Base, Challenges, Opportunities and Areas for Future Research. Available online: https://www.cifor.org/knowledge/publication/5135/ (accessed on 15 May 2020).

31. Mickleburgh, S.; Waylen, K.; Racey, P. Bats as bushmeat: A global review. Oryx 2009, 43, 217-234. [CrossRef]

32. Frick, W.F.; Kingston, T.; Flanders, J. A review of the major threats and challenges to global bat conservation. Ann. N. Y. Acad. Sci. 2019. [CrossRef]

33. Mildenstein, T.; Tanshi, I.; Racey, P.A. Exploitation of bats for bushmeat and medicine. In Bats in the Anthropocene: Conservation of Bats in a Changing World; Voigt, C.C., Kingston, T., Eds.; Springer International Publishing: Cham, Switzerland, 2016; pp. 325-375, ISBN 978-3-319-25220-9.

34. Tong, S.; Conrardy, C.; Ruone, S.; Kuzmin, I.V.; Guo, X.; Tao, Y.; Niezgoda, M.; Haynes, L.; Agwanda, B.; Breiman, R.F.; et al. Detection of novel SARS-like and other coronaviruses in bats from Kenya. Emerg. Infect. Dis. 2009, 15, 482-485. [CrossRef]

35. Quan, P.-L.; Firth, C.; Street, C.; Henriquez, J.A.; Petrosov, A.; Tashmukhamedova, A.; Hutchison, S.K.; Egholm, M.; Osinubi, M.O.V.; Niezgoda, M.; et al. Identification of a severe acute respiratory syndrome coronavirus-like virus in a leaf-nosed bat in Nigeria. mBio 2010, 1. [CrossRef] [PubMed]

36. Ithete, N.L.; Stoffberg, S.; Corman, V.M.; Cottontail, V.M.; Richards, L.R.; Schoeman, M.C.; Drosten, C.; Drexler, J.F.; Preiser, W. Close Relative of human middle east respiratory syndrome coronavirus in bat, South Africa. Emerg. Infect. Dis. 2013, 19, 1697-1699. [CrossRef] [PubMed]

37. Annan, A.; Baldwin, H.J.; Corman, V.M.; Klose, S.M.; Owusu, M.; Nkrumah, E.E.; Badu, E.K.; Anti, P.; Agbenyega, O.; Meyer, B.; et al. Human betacoronavirus 2c EMC/2012-related viruses in bats, Ghana and Europe. Emerg. Infect. Dis. 2013, 19, 456-459. [CrossRef]

38. Razanajatovo, N.H.; Nomenjanahary, L.A.; Wilkinson, D.A.; Razafimanahaka, J.H.; Goodman, S.M.; Jenkins, R.K.; Jones, J.P.; Heraud, J.-M. Detection of new genetic variants of betacoronaviruses in endemic frugivorous bats of Madagascar. Virol. J. 2015, 12, 42. [CrossRef]

39. Bourgarel, M.; Pfukenyi, D.M.; Boué, V.; Talignani, L.; Chiweshe, N.; Diop, F.; Caron, A.; Matope, G.; Missé, D.; Liégeois, F. Circulation of alphacoronavirus, betacoronavirus and paramyxovirus in hipposideros bat species in Zimbabwe. Infect. Genet. Evol. 2018, 58, 253-257. [CrossRef]

40. Joffrin, L.; Goodman, S.M.; Wilkinson, D.A.; Ramasindrazana, B.; Lagadec, E.; Gomard, Y.; Le Minter, G.; Dos Santos, A.; Corrie Schoeman, M.; Sookhareea, R.; et al. Bat coronavirus phylogeography in the Western Indian Ocean. Sci. Rep. 2020, 10, 6873. [CrossRef]

41. Maganga, G.D.; Pinto, A.; Mombo, I.M.; Madjitobaye, M.; Mbeang Beyeme, A.M.; Boundenga, L.; Ar Gouilh, M.; N’Dilimabaka, N.; Drexler, J.F.; Drosten, C.; et al. Genetic diversity and ecology of coronaviruses hosted by cave-dwelling bats in Gabon. Sci. Rep. 2020, 10, 1-13. [CrossRef] 
42. Nziza, J.; Goldstein, T.; Cranfield, M.; Webala, P.; Nsengimana, O.; Nyatanyi, T.; Mudakikwa, A.; Tremeau-Bravard, A.; Byarugaba, D.; Tumushime, J.C.; et al. Coronaviruses detected in bats in close contact with humans in Rwanda. Ecohealth 2020, 17, 152-159. [CrossRef]

43. Anthony, S.J.; Gilardi, K.; Menachery, V.D.; Goldstein, T.; Ssebide, B.; Mbabazi, R.; Navarrete-Macias, I.; Liang, E.; Wells, H.; Hicks, A.; et al. Further evidence for bats as the evolutionary source of Middle East respiratory syndrome coronavirus. MBio 2017, 8. [CrossRef]

44. De Nys, H.M.; Kingebeni, P.M.; Keita, A.K.; Butel, C.; Thaurignac, G.; Villabona-Arenas, C.-J.; Lemarcis, T.; Geraerts, M.; Vidal, N.; Esteban, A.; et al. Survey of ebola viruses in frugivorous and insectivorous bats in Guinea, Cameroon, and the Democratic Republic of the Congo, 2015-2017. Emerg. Infect. Dis. 2018, 24. [CrossRef]

45. Irwin, D.M.; Kocher, T.D.; Wilson, A.C. Evolution of the cytochromeb gene of mammals. J. Mol. Evol. 1991, 32, 128-144. [CrossRef] [PubMed]

46. Chu, D.K.W.; Leung, C.Y.H.; Gilbert, M.; Joyner, P.H.; Ng, E.M.; Tse, T.M.; Guan, Y.; Peiris, J.S.M.; Poon, L.L.M. Avian coronavirus in wild aquatic birds. J. Virol. 2011, 85, 12815-12820. [CrossRef] [PubMed]

47. Trifinopoulos, J.; Nguyen, L.-T.; von Haeseler, A.; Minh, B.Q. W-IQ-TREE: A fast online phylogenetic tool for maximum likelihood analysis. Nucleic Acids Res. 2016, 44, W232-W235. [CrossRef] [PubMed]

48. Minh, B.Q.; Schmidt, H.A.; Chernomor, O.; Schrempf, D.; Woodhams, M.D.; von Haeseler, A.; Lanfear, R. IQ-TREE 2: New models and efficient methods for phylogenetic inference in the genomic era. Mol. Biol. Evol. 2020, 37, 1530-1534. [CrossRef]

49. Nesi, N.; Nakouné, E.; Cruaud, C.; Hassanin, A. DNA barcoding of African fruit bats (Mammalia, Pteropodidae). The mitochondrial genome does not provide a reliable discrimination between Epomophorus gambianus and Micropteropus pusillus. C. R. Biol. 2011, 334, 544-554. [CrossRef]

50. Wong, A.C.P.; Li, X.; Lau, S.K.P.; Woo, P.C.Y. Global epidemiology of bat coronaviruses. Viruses 2019, 11, 174. [CrossRef]

51. Tao, Y.; Shi, M.; Chommanard, C.; Queen, K.; Zhang, J.; Markotter, W.; Kuzmin, I.V.; Holmes, E.C.; Tong, S. Surveillance of bat coronaviruses in kenya identifies relatives of human coronaviruses NL63 and 229E and their recombination history. J. Virol. 2017, 91. [CrossRef]

52. Geldenhuys, M.; Weyer, J.; Nel, L.H.; Markotter, W. Coronaviruses in South African bats. Vector Borne Zoonotic Dis. 2013, 13, 516-519. [CrossRef]

53. Gloza-Rausch, F.; Ipsen, A.; Seebens, A.; Göttsche, M.; Panning, M.; Drexler, J.F.; Petersen, N.; Annan, A.; Grywna, K.; Müller, M.; et al. Detection and prevalence patterns of group i coronaviruses in bats, Northern Germany. Emerg. Infect. Dis. 2008, 14, 626-631. [CrossRef]

54. Drexler, J.F.; Corman, V.M.; Wegner, T.; Tateno, A.F.; Zerbinati, R.M.; Gloza-Rausch, F.; Seebens, A.; Müller, M.A.; Drosten, C. Amplification of emerging viruses in a bat colony. Emerg. Infect. Dis. 2011, 17, 449-456. [CrossRef]

55. Wacharapluesadee, S.; Duengkae, P.; Chaiyes, A.; Kaewpom, T.; Rodpan, A.; Yingsakmongkon, S.; Petcharat, S.; Phengsakul, P.; Maneeorn, P.; Hemachudha, T. Longitudinal study of age-specific pattern of coronavirus infection in Lyle's flying fox (Pteropus lylei) in Thailand. Virol. J. 2018, 15, 38. [CrossRef]

56. Anthony, S.J.; Johnson, C.K.; Greig, D.J.; Kramer, S.; Che, X.; Wells, H.; Hicks, A.L.; Joly, D.O.; Wolfe, N.D.; Daszak, P.; et al. Global patterns in coronavirus diversity. Virus Evol. 2017, 3, vex012. [CrossRef] [PubMed]

57. Kock, D.; Arm, Z.; Mickleburgh, A.M.; Bergmans, W.; Aulagnier, S. IUCN Red List of Threatened Species: Sundevall's Roundleaf Bat. Available online: https://www.iucnredlist.org/en (accessed on 26 May 2020).

58. Hutson, A.; Mickleburgh, S.; Bergmans, W.; Fahr, J.; Swaziland, A.M. University of IUCN Red List of Threatened Species: Noack's Roundleaf Bat. Available online: https://www.iucnredlist.org/en (accessed on 26 May 2020).

59. Maganga, G.D.; Bourgarel, M.; Vallo, P.; Dallo, T.D.; Ngoagouni, C.; Drexler, J.F.; Drosten, C.; Nakouné, E.R.; Leroy, E.M.; Morand, S. Bat distribution size or shape as determinant of viral richness in African bats. PLOS ONE 2014, 9. [CrossRef]

60. Ge, X.-Y.; Wang, N.; Zhang, W.; Hu, B.; Li, B.; Zhang, Y.-Z.; Zhou, J.-H.; Luo, C.-M.; Yang, X.-L.; Wu, L.-J.; et al. Coexistence of multiple coronaviruses in several bat colonies in an abandoned mineshaft. Virol. Sin. 2016, 31, 31-40. [CrossRef] [PubMed] 
61. Wu, Z.; Yang, L.; Ren, X.; Zhang, J.; Yang, F.; Zhang, S.; Jin, Q. ORF8-related genetic evidence for Chinese horseshoe bats as the source of human severe acute respiratory syndrome coronavirus. J. Infect. Dis. 2016, 213, 579-583. [CrossRef] [PubMed]

62. Valitutto, M.T.; Aung, O.; Tun, K.Y.N.; Vodzak, M.E.; Zimmerman, D.; Yu, J.H.; Win, Y.T.; Maw, M.T.; Thein, W.Z.; Win, H.H.; et al. Detection of novel coronaviruses in bats in Myanmar. PLoS ONE 2020, 15, e0230802. [CrossRef]

63. Chu, D.K.W.; Peiris, J.S.M.; Chen, H.; Guan, Y.; Poon, L.L.M. Genomic characterizations of bat coronaviruses (1A, 1B and HKU8) and evidence for co-infections in Miniopterus bats. J. Gen. Virol. 2008, 89, 1282-1287. [CrossRef]

64. Lau, S.K.P.; Li, K.S.M.; Huang, Y.; Shek, C.-T.; Tse, H.; Wang, M.; Choi, G.K.Y.; Xu, H.; Lam, C.S.F.; Guo, R.; et al. Ecoepidemiology and complete genome comparison of different strains of severe acute respiratory syndrome-related rhinolophus bat coronavirus in China reveal bats as a reservoir for acute, self-limiting infection that allows recombination events. J. Virol. 2010, 84, 2808-2819. [CrossRef]

65. Johnson, C.K.; Hitchens, P.L.; Smiley Evans, T.; Goldstein, T.; Thomas, K.; Clements, A.; Joly, D.O.; Wolfe, N.D.; Daszak, P.; Karesh, W.B.; et al. Spillover and pandemic properties of zoonotic viruses with high host plasticity. Sci. Rep. 2015, 5, 14830. [CrossRef]

66. Leopardi, S.; Holmes, E.C.; Gastaldelli, M.; Tassoni, L.; Priori, P.; Scaravelli, D.; Zamperin, G.; De Benedictis, P. Interplay between co-divergence and cross-species transmission in the evolutionary history of bat coronaviruses. Infect. Genet. Evol. 2018, 58, 279-289. [CrossRef]

67. Fenton, M.B.; Simmons, N.B. Bats: A World of Science and Mystery; University of Chicago Press: Chicago, IL, USA, 2015; ISBN 978-0-226-06512-0.

(C) 2020 by the authors. Licensee MDPI, Basel, Switzerland. This article is an open access article distributed under the terms and conditions of the Creative Commons Attribution (CC BY) license (http://creativecommons.org/licenses/by/4.0/). 